\title{
Ilpo Saunio ja suomalainen etnomusikologia
}

Tässä kirjoituksessa luotailen viime talvena kuolleen ystäväni ja työtoverini Ilpo Saunion uraa suomalaisessa musiikkielämässä. Erityinen painopiste on Ilpon toiminnan niissä alueissa, jotka ovat keskeisimmin liittyneet suomalaisen etnomusikologian kehitykseen: ulkoeurooppalaisen musiikin tunnetuksi tekeminen, kansanmusiikin ja populaarimusiikin tutkimus sekä musiikkipolitiikka. Käytössäni on ollut Ilpon laaja lehtileikekokoelma ${ }^{1}$, joskin sen hyödyntäminen ei ollut aivan ongelmatonta. Suurin osa leikkeistä on vailla viitetietoja, eikä minulla ole ollut mahdollisuutta selvittää kaikkien mielenkiintoisten juttujen alkuperää. Lisäksi Ilpo Saunion elämäntyö liittyi niin laajoihin musiikkielämän tapahtumiin ja kehityslinjoihin, että niiden tasapuolinen käsittely vaatisi huomattavasti monipuolisemman lähdeaineiston käyttöä.

Kirjoitus jää väkisinkin muistelmatyyppiseksi ja subjektiiviseksi, vaikka mielessäni on väikkynyt myös kunnianhimoisempi päämäärä. Haluaisin että tämä juttu olisi myös pieni panos musiikintutkimuksen oppihistoriaan, jonka tutkimus on ollut Suomessa melko vähäistä. Oman menneisyyden pohdiskelusta saa aina perspektiiviä nykytilanteeseen. Modernin etnomusikologian alkutaipaleen tarkastelu tuntuu erityisen tärkeältä nyt, kun ala on vakiintumassa ja kun etnomusikologian ja perinteisen musiikkitieteen näkemyserot näyttävät olevan katoamassa. Pyrin seuraavassa nostamaan Ilpo Saunion henkilöhistoriasta näkökulmia, jotka liittyvät erityisesti musiikkielämän ristiriitoihin ja arvokamppailuihin. Toivon samalla, että joku voisi niitä myöhemmin hyödyntää. Vielä hienompaa tietysti olisi, jos joku pyrkisi ne kiistämään ja veisi sillä tavoin oppihistorian tutkimusta eteenpäin.

Amerikkalaismallinen etnomusikologia rantautui Suomeen näkyvämmin vasta 1970-luvun alussa. Sille oli tyypillistä ainakin seuraavat neljä piirrettä: uusi etnomusikologia kehittyi ilman näkyviä ja arvostettuja yliopistovirkoja tai kokonaan akateemisten piirien ulkopuolella. Toiseksi sillä oli jokseenkin läheinen suhde kulttuuriradikalismiin ja vasemmistolaisuuteen, jossa kulttuurin arvojen uudelleenarviointi oli ainakin aluksi keskeisellä sijalla. Lisäksi ja edellisestä johtuen moderni

${ }^{1}$ Kiitokset Petri Sauniolle siitä, että Ilpon kirjallinen ja kuvallinen jäämistö on ollut vapaasti saatavilla yhteisten muisteluiden kera. 


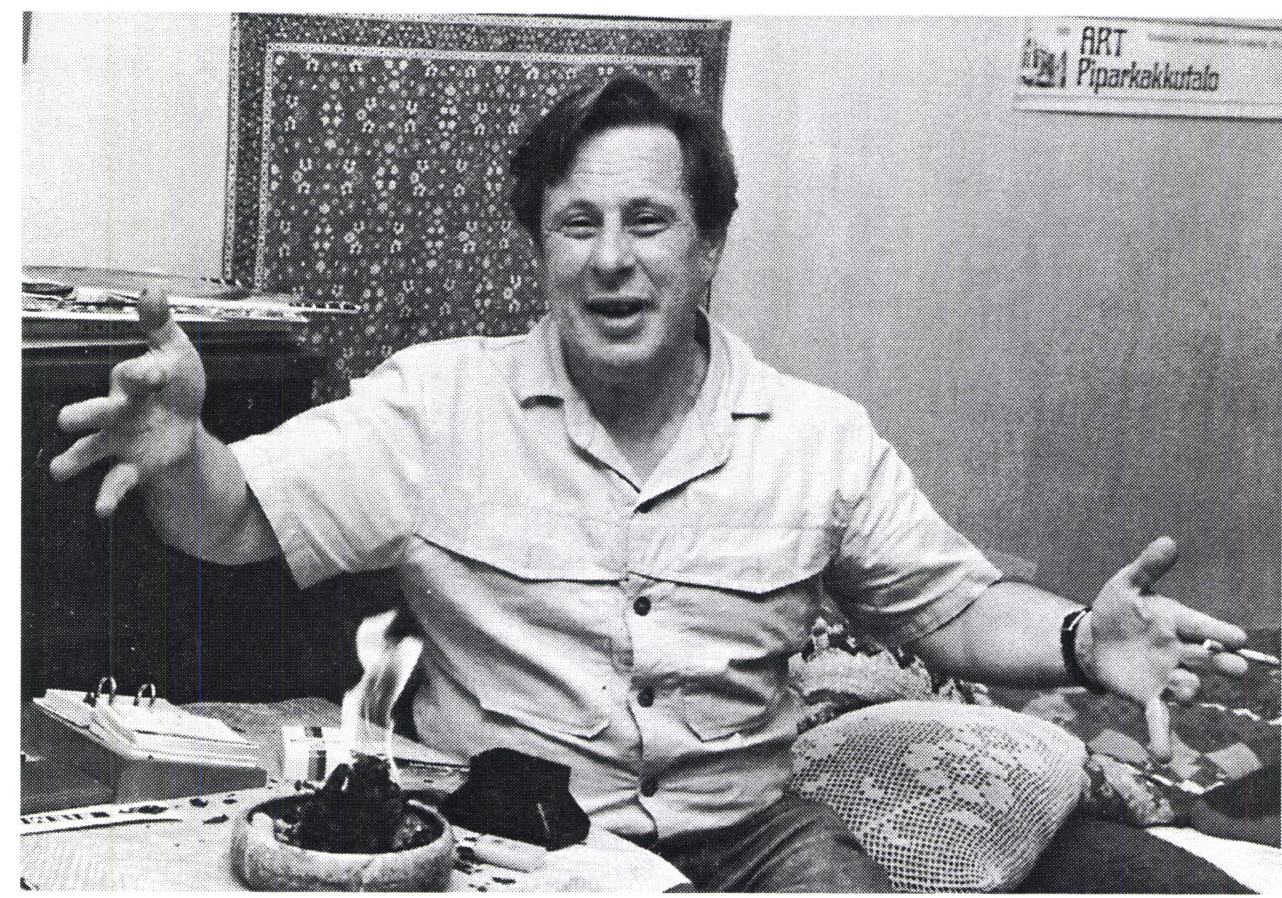

1960-luvun lopulla Ilpo Saunio poltti julkisesti sotilaspassinsa yhdessä muutaman muun pasifistisen intelligentin kanssa. Sodanvastainen mielenilmaus oli varsin tyypillinen osa 60-luvun kulttuurikapinaa, jossa päivän kysymyksiä olivat Vietnamin sota ja aseistariisunta. Parikymmentä vuotta myöhemmin Suomen valtio lähetti vänrikki Sauniolle uuden passin, ja Ilpo päätti juhlistaa sotilaallis-pasifistista uraansa polttamalla passinsa uudelleen. Ilpo iloisissa passinpolttopuuhissa kotinsa keittiössä. (Päiväämätön valokuva 1980-luvun jälkipuolelta, kuvaaja tuntematon.)

etnomusikologia oli varsin osallistuvaa, monet sen pioneereista pyrkivät vaikuttamaan musiikkipolitiikkaan. Edelleen uusi etnomusikologia kontrastoi voimakkaasti vanhempaan akateemiseen kansanmusiikintutkimukseen, koska sen pääpaino oli muualla kuin kansallisessa kulttuurissa. Kiinnostuksen kohteena oli nyt kolmas maailma, työväestö ja vähemmistöt. Teemat vastasivat hyvin 1960-luvun nuoren älymystön uusia kiinnostuksen kohteita.

Miksi etnomusikologia joutui Suomessa näin korostuneeseen oppositioasemaan? Näinhän ei käynyt esimerkiksi Ruotsissa, missä musiikintutkimuksen marxilaiset ja kulttuuriantropologiset suuntaukset sulautuivat ilmeisen kivuttomasti vallitsevan musiikkitieteen helmoihin. Tämä tapahtui nimenomaan akatemian sisäpuolella.

${ }^{2}$ Suomalaisen ja ruotsalaisen akateemisen musiikkitieteen ero näkyy erinomaisen hyvin, kun vertailee millaista musiikinhistoriaa näissä maissa on viime vuosina kirjoitettu. Molemmissa maissa saatiin 1990-luvun puoliväliin mennessä valmiiksi moniosaiset ja laajaan tutkimustyöhön perustuneet kansalliset musiikinhistoriat, Ruotsissa Musiken i Sverige ja Suomessa Suomen musiikin historia. Niiden välittämä kuva kansallisen musiikin menneisyydestä poikkeaa ratkaisevasti toisestaan. Siinä missä suomalainen historiankirjoitus keskittyi pelkästään 'luovaan säveltaiteeseen', ts. taidemusiikin säveltäjiin, ruotsalainen teos käsittelee kaikkia musiikin osa-alueita ja on muutenkin moniarvoisempi tutkimusot- 
Samalla Ruotsin musiikkitieteessä kehittyi kansainvälisesti merkittävä koulukunta populaarimusiikin tutkimuksen alueella. Tämä kaikki näkyi erityisen selvästi Göteborgissa, missä Jan Ling alkoi kehittää varsin omaperäistä musiikkitieteen opetusta vuodesta 1967 lähtien. ${ }^{2}$

Mutta Suomessa uuden etnomusikologian kotiutuminen yliopistoihin kesti pitempään. Suomalaisen etnomusikologian alkutaivalta etsittäessä yliopisto kannattaa kiertää kaukaa. Ilpo Saunion ja Pekka Gronowin kaltaiset pioneerit pysyttelivät visusti akatemian ulkopuolella ja heidän kirjoituksensa olivat journalistisia ja usein mitä suurimmassa määrin poliittisesti kantaa ottavia.

Moni akateemista uraa tekevä etnomusikologi ei ehkä hyväksy tulkintaani, että mainitut lehtisenttaukset kuuluisivat tieteen piiriin. Vakiintuneessa tutkijayhteisössä tiede halutaan erottaa tiedon populaaristamisesta ja politiikan teosta. Mutta 1960- ja 1970lukujen tilanne oli paljolti toisenlainen. Tuon ajan radikaalien käsityksissä myös tiede oli äärimmäisen poliittista, ja hyvän tieteen kriteeriksi kohosi usein tutkimuksen suhde marxilaisuuteen. Varsin kuvaava ajan hengen kannalta oli Seppo Toiviaisen (1970) sosiologian väitöskirja "Yhteiskunnalliset ja kulttuuriset ristiriidat - musikologisten osakulttuurien sosiologista tarkastelua" ja sen synnyttämä keskustelu.

Toiviaisen tutkimus oli ajalle tyypillinen postikyselyyn perustuva survey-tutkimus suomalaisten musiikkimausta ja -asenteista. Faktorianalyysin avulla Toiviainen sai esiin kolme makuryhmää (mt., 44-45), joita hän nimitti musikologisiksi osakulttuureiksi: klassis-viihteellisen konserttimusiikin suosijat, jotka olivat vanhempia naisia, kaupunkilaisia ja koulutettuja, perinnemusiikin kannattajat, jotka olivat vanhempia vähän kouluja käyneitä maalaisia sekä amerikkalaisvaikutteisesta musiikista pitävät, kouluja käyneet kaupunkilaisnuoret. Tutkimus sisälsi myös melko suppean marxilaiseen yhteiskuntateoriaan perustuvan loppujakson, jossa Toiviainen tulkitsi musiikkimaun erojen heijastavan yhteiskunnallisia ristiriitoja.

Jälkikäteen arvioituna Toiviaisen väitöskirjalla ei ollut kovin paljon vaikutusta sen enempää suomalaiseen musiikintutkimukseen kuin taiteen sosiologiaankaan. Mutta se heijasteli hyvin 1970-luvun alussa käytyä musiikkikeskustelua, erityisesti monipuolisemman musiikkipolitiikan puolustajien näkemyksiä. Toiviainen nosti esiin monia uusia näkökulmia. Hänelle musiikki oli nimenomaan sosiaalinen ilmiö, ja mikä olennaista, eri sosiaaliryhmillä oli omat musiikkinsa. Lisäksi Toiviainen käsitteli eri musiikkimaailmoja tasa-arvoisesti, arvottamatta niitä mitenkään sisällön perusteella. Ei olekaan ihme, että myös Ilpo Saunio innostui aiheesta. Se sai hänet vertaamaan työtä myös akateemisen musiikkitieteen sen aikaiseen tilanteeseen:

teeltaan. Tämän eron on nostanut esille mm. prof. Fabian Dahlström, joka oli yksi Suomen musiikin historian kirjoittajista ja seurannut samalla läheltä muita pohjoismaisia musiikinhistorian tutkimusprojekteja (seminaarialustus Kaustisella, helmikuu 2000). 
Tässä ja nyt on kuitenkin todettava, että se [Toiviaisen tutkimus] on ensimmäinen suomalainen merkittävä musiikkitieteellinen väitöskirjatasoinen tutkimus. Musiikkisosiologian uranuurtaja Alphons Silbermann toteaa ilkeämielisesti musiikkihistoriallisten selvitysten kuuluvan joko anekdootteihin, myytteihin tai romansseihin. Toiviaisen tutkimus ei kuulu näihin kategorioihin. Sen merkitys suomalaiselle musiikintutkimukselle ja käytännön musiikkipolitiikalle on suurempi kuin esimerkiksi prof. Erik Tawaststjernan kymmenen vuotta aiemmin ilmestyneeseen väitöskirjan "Sibeliuksen pianoteokset säveltäjän kehityslinjan kuvastajana", jolla hän pääsi Helsingin yliopiston musiikkitieteen professoriksi. Tawaststjernan väitöskirja on esimerkki musikologisten, selitettävien muuttujien esteettisestä (ja suurimmalta osalta jokseenkin tarpeettomasta) tarkastelusta, jollaisesta toivottavasti aletaan musiikkitieteessä vähitellen luopua. Postiluukustani tipahti tätä kirjoittaessani Grazin musiikki- ja esittävän taiteen korkeakoulun (jossa on mm. Euroopan merkittävin jazz-instituutti) uusi opinto-opas, joka alkaa koulun rehtorin esipuheella: 'Taiteen olemus ei ole käsitettävissä esteettisesti vaan elämän fenomeeninä ...'(Saunio 1971)

Musikologisten muuttujien esteettistä pohdintaa ei ole musiikkitieteessä tietenkään lopetettu. Mutta eräässä suhteessa Ilpon kommentti ennusti tulevaisuutta. Musiikin käsittäminen "elämän fenomeenina" oli juuri sitä, mistä etnomusikologit taukoamatta puhuivat musiikki kulttuurina -teeseissään. Se oli myös sitä, johon suuntaan myös perinteinen musiikkitiede on yhä enemmän edennyt 1990-luvulla kontekstuaalisuuden korostamisen ja ns. lingvistisen käänteen myötä.

\section{Kansanvalistaja-Ilpo}

Olen käynyt läpi Ilpo Saunion kirjoituksia etupäässä 1960-luvun lopulta alkaen. Tuolloin hänellä oli takanaan jo yli kymmenvuotinen ura musiikkiarvostelijana. Tuo varhaisempi kriitikontaival olisi sinällään selvittämisen arvoinen, mutta ei ehkä niin keskeinen etnomusikologian historian kannalta. 1960-luvun loppuun mennessä Ilpo oli ehtinyt toimia musiikkiarvostelijana monissa eri lehdissä: Kirkko ja musiikki, Uusi Suomi, Ylioppilaslehti, Teekkari, Terä ja Kansan Uutiset.

Lehtien nimet ja sisältö kertovat samalla Ilpo Saunion kirjoittajanuran muutoksen. Aluksi juttujen keskipisteenä oli normaali konserttitarjonta, joskin saman aikaisesti Ilpo toimi suorastaan intohimoisesti uuden musiikin puolestapuhujana. Vuonna 1965 Ilpo teki näkyvän siirtymisen laitavasemmistoon ja pestautui Suomen Demokraattisen Nuorisoliiton Terä-lehden toimittajaksi. Värin tunnustaminen oli ajankohtaan nähden melko radikaalia, sillä nuoren älymystön joukkoloikka vasemmalle tapahtui vasta vuosikymmenen lopulla.

Ilpon juttujen aiheet muuttuivat selvästi. Modernia taidemusiikkia ruotivat kirjoitukset jäivät pois, eikä Ilpo enää tehnyt normaalia konserttikritiikkiäkään, paitsi poliittisen musiikin konserteista. Tilalle tulivat teemat, jotka sittemmin hallitsivat Ilpon journalistista ja tieteellistä toimintaa loppuun saakka: ulkoeuroopalainen 
musiikki, jazz, "edistyksellinen" rock, populaarimusiikin aseman puolustaminen, ns. uusi laulu ja ennen kaikkea vanhempi työväenlaulu, jolla alueella Ilposta tuli maan johtava asiantuntija. 1960-luvun puoliväliin juontaa juurensa myös Ilpon kiinnostus Afrikkaa kohtaan; ensimmäinen Afrikka-juttu Terässä käsitteli Tansanian yhteiskunnallisia oloja - Ilpo oli päässyt lyhyelle vierailulle Dar-es-Salaamiin jonkin kansainvälisen solidaarisuuskokouksen yhteydessä (Saunio 1966). Myöhemmin kiinnostus ulkoeurooppalaista musiikkia ja kulttuuria kohtaan laajeni kaikkiin ilmansuuntiin, ensin Neuvostoliiton kansoihin ja sittemmin mm. Oseaniaan ja EteläAmerikkaan.

Jo nuoruusajan jutuissa tulee esiin kaksi Ilpon perusominaisuutta, perusteellisuus ja poleemisuus. Perusteellisuus heijastui suoraan juttujen pituuteen; monet artikkelit uudesta musiikista, jazzista tai kuuluisista pianisteista olivat useiden kymmenien liuskojen pienoistutkielmia. Niistä heijastui Ilpon intohimo tarjota lukijoille uutta tietoa asioista, joita hän piti tärkeinä. Kirjoittelusta heijastui tietty pyrkimys kansanvalistukseen, mikä oli ilmeisen myötäsyntyinen ominaisuus useimmille Ilpon ikäluokan älyköille. Näinhän myös 60-luvun radikaalien isät ja isoisät olivat toimineet. Vain aatteet olivat muuttuneet, ei itse mentaliteetti.

Ilpo Saunion kirjoittajanuran aikana noita perusteellisia lehtijuttuja syntyi hyvin monenlaisista aiheista. Erityisesti 1970-luvulla, jolloin Ilpo joutui elättämään itsensä lehtikirjoittajana, pitkät jutut olivat suosiossa. Ilpon pääfoorumina oli kuitenkin Kansan Uutiset, poliittinen päivälehti, johon usean kymmenen liuskan jutut eivät olisi mitenkään mahtuneet. Ilpo ratkaisi ongelman käyttämällä vanhaa, jo 1800luvun kirjailijoiden suosimaa keinoa, jatkojuttuja ja juttusarjoja. Seikkaperäisiä etnisen musiikin esittelyjä syntyi mm. seuraavien otsikkojen alla: Sata vuotta työväenlauluja 1-3, Saksalaista työväenlaulua 1-5, Musiikkia politiikan polttopisteessä 1-11, 50-vuotiaan SNTL:n musiikkia 1-8. Näissä kirjoitussarjoissa ja lukuisissa yksittäisissä teemajutuissa Ilpo esitteli 1970-luvun mittaan melkoisen määrän musiikkikulttuureja kaikilta mantereilta. Suuri osa jutuista perustui tuolloin vielä vaikeasti saataviin äänitteisiin ja ulkomaisiin kirjoihin.

Äänitteiden ja kirjojen keruu oli Ilpon suuri intohimo, joka vielä täydentyi uusimman hifi-tietouden tutkimisella ja kirjoittelulla alan lehtiin. Ilpon tapauksessa äänilevyjen keruu johti perinpohjaiseen tutkimustyöhön, ja hänestä tulikin Pekka Gronowin rinnalle äänilevytutkimuksen suomalainen auktoriteetti; parivaljakon tiiliskivimäinen Äänilevyn historia (Gronow \& Saunio 1990, ensi laitos 1970) tulee epäilemättä olemaan alan merkkiteos vielä pitkään. Kirja ilmestyi myös englanniksi pari vuotta sitten (Gronow \& Saunio 1998).

Ilpo Saunion ansiosta Kansan Uutisten kulttuuritoimituksesta tuli todellinen edelläkävijä maailman musiikkikulttuurien ja etnisten äänitteiden esittelijänä. On syytä muistaa, että 1970-luvulla esimerkiksi Helsingin Sanomilla ei ollut yhtään vakituista avustajaa kansanmusiikin alueella. Toinen asia sitten on, kuinka hyvin Kansan 
Uutisissa julkaistut kirjoitukset tavoittivat maailman musiikista kiinnostuneet kansandemokraattisen liikkeen ulkopuolella. Itse en ainakaan muista lukeneeni niitä koskaan.

Erityisen merkittävää oli tutustuminen Neuvostoliiton kansojen musiikkeihin; niistähän oli vielä tuohon aikaan hyvin vaikea saada tietoa ja ääniteaineistoa. SuomiNeuvostoliitto -seuran ja Yleisradion yhteyksien avulla Ilpo onnistui hankkimaan hyvin ainutlaatuisia äänitteitä mm. Melodija-yhtiöstä ja eri neuvostotasavaltojen radioiden arkistoista. Hieman myöhemmin tämä sinnikäs perehtyminen poiki monikymmenosaisen radio-ohjelman, jonka käsikirjoitukset ilmestyivät myös kirjana "Pororumpu ja balalaikka - Neuvostoliiton kansojen musiikki" (Saunio ja Immonen 1979). ${ }^{3}$

Ilpo Saunion aktiivisuus etnomusikologisen tiedon populaaristajana jatkui vielä 1980-luvullakin, nyt yhä useammin myös alkuaskeleitaan ottavan Suomen etnomusikologisen seuran piirissä. Monista perinpohjaisista jutuista haluan erityisesti mainita vuonna 1981 Folk \& country -lehdessä ilmestyneen kaksiosaisen henkilökuvan Pete Seegeristä ja USA:n folk-liikkeestä. Ilpolle tyypilliseen tapaan jutun käsikirjoitus oli reilut puolensataa sivua ja se oli varustettu pitkällä kirjallisuus- ja äänilevyluettelolla. Pitkien juttujen huippuna oli epäilemättä Musiikin Suunta -lehden Etiopia-numero (Saunio 1986). Lehteen piti alunperin saada pidempiä juttuja useilta kirjoittajilta, mutta kuten pienlehdissä usein käy, lähes koko kirjoitusvastuu kaatui hanketta vetävän Ilpon niskaan. Etiopia-numeron kokonaispituudeksi tuli puolentoista sataa sivua; laajin juttu oli Ilpon yli satasivuinen kirjoitus "Etiopian musiikki. Suuri linja antiikista nykypäivään". Ilpon perusteellisuus tuotti jälleen ainutlaatuista tietoa, tällä kertaa varsin tuntemattoman itäafrikkalaisen kulttuurialueen musiikkien historiasta ja ominaispiirteistä.

\section{Poleemikko-Ilpo}

Poleemisuus oli Ilpon keino synnyttää julkista keskustelua hänelle tärkeistä asioita. Hyvä esimerkki on Uudessa Suomessa vuonna 1962 tehty kiertokysely (Anon.), jossa tiedusteltiin helsinkiläisen konserttiyleisön mielipidettä konserttitarjonnasta. 22vuotias Ilpo Saunio oli ilmeisesti valittu nuorten radikaalien edustajaksi, eikä Ilpon vastaus pettänyt toiveita. Hän totesi ykskantaan, että koko klassis-romanttinen repertuaari pitäisi kieltää orkesterien ohjelmistoista joksikin aikaa. Näin yleisö tottuisi modernin musiikin kieleen eikä enää vieroksuisi sitä. Kapellimestari Tauno

\footnotetext{
3 Ääninauhat ovat nykyisin Tampereen yliopiston kansanperinteen laitoksen arkistossa odottamassa digitoimistaan. Myös radio-ohjelmien ääniteaineisto on kopioitu kansanperinteen laitoksen arkistoon.
} 
Hannikainen ja intendentti Aulis Sallinen joutuivat hieman kiusaantuneina vastaamaan Ilpon kommenttiin, mikä saattoi olla myös kommentoijan perimmäinen tarkoitus.

Ilpo Saunion vasemmistolaistuminen merkitsi myös sitä, että hän muuttui modernin musiikin kannattajasta populaarikulttuurin puolustajaksi. Hän oli tässä kysymyksessä huomattavasti jyrkempi kuin monet kansandemokraattiseen liikkeeseen sitoutuneet kirjallisuuden tai teatterin ammattilaiset. Hyvä esimerkki Ilpon ehdottomuudesta oli vuonna 1969 käyty kulttuurikeskustelu Kansan Uutisissa.

Keskustelun taustalla oli kaksi vuotta aiemmin käyty väittely, joka oli saanut alkunsa akateemikko Joonas Kokkosen Jyväskylän kesässä pitämästä puheesta. Kokkonen hyökkäsi varsin tiukin sanoin 60-luvun osallistuvaa taidetta ja viihdekulttuuria kohtaan syyttäen radikaaleja taiteen politisoinnista ja korostamalla taiteen ja viihteen välistä laadullista eroa. Jo tuolloin Ilpo Saunio puolusti innokkaasti osallistuvaa taidetta sekä toi esiin taide-viihde -jaottelun keinotekoisuuden ja vaatimuksen moniarvoisemmasta musiikkipolitiikasta:

\begin{abstract}
Kysymys on vain yrityksestä antaa kaikkien kukkien kukkia, yrityksestä järkyttää edes vähän klassisen musiikin ja klassisten muusikkojen väärää monopoliasemaa virallisessa arvostuksessa ja musiikkipolitiikassa. Kysymys on sorrettujen ja halveksittujen taistelusta oikeudenmukaisuuden puolesta. - - Kysymys on ehkä enemmänkin siitä, että kummankin, sekä vakavan että populaarimusiikin piirissä luodaan yhtä hyvin sekä "taiteeksi" katsottavia huipputuloksia että "viihteeksi" katsottavaa rihkamaa. Mitä on Beethovenin Für Elise tai Fibichin Poème? Rajat kulkevat jossain kokonaan muualla kuin klassisen musiikin edustajat yleensä yrittävät itselleen uskotella. (Saunio 1967)
\end{abstract}

Kolme vuotta myöhemmin arvokiista leimahti uudelleen, nyt vasemmiston sisällä. Kimmoke tuli neuvostoliittolaisen APN:n julkaisemasta kirjasesta "Sosialismi ja kulttuuriperintö", jonka klassisia arvoja korostava taidekäsitys ja massakulttuurikritiikki sai Ilpo Saunion mielen kuohahtamaan. Seurauksena oli pitkä populaarikulttuurin puolustuspuheenvuoro, jossa Ilpo määritteli ja eritteli itse asiassa kaikki musiikin arvokeskustelun osatekijät ja paljon muutakin: massakulttuurin, populaarikulttuurin, sosialistisen kulttuurin, kulttuurikolonialismin ja kulttuuripolitiikan. Olen koonnut seuraavaan Ilpon kommentit kustakin kysymyksestä. Lainaukset saattavat tuntua turhan pitkiltä, mutta Ilpo Saunion kirjoitustyyli ei oikein välity lyhemmistä sitaateista.

massakulttuuri:

[APN:n kirjan] kirjoittaja Eleazar Baller puhuu "massakulttuurista" välittömänä seurauksena ristiriidoista, jotka ovat ominaiset yhteiskunnalle, jossa aineelliset ja henkiset arvot eivät palvele ihmistä, vaan päinvastoin ovat sille vieras ja vihamielinen voima. - - Mitä tämä on? Käsitteiden sekaannusta, mahdollisesti jopa melkoista tietämättömyyttä populaarikulttuurista. Miten Ballerin määritelmä sopii esimerkiksi sellaisen alunperin neekereiden massakulttuurin ilmiöön kuin bluesiin, joka tosin nykyisin on valkoisten muusikoiden esittämänä tun- 
keutunut myös eurooppalaiseen musiikkimaailmaan? On varmasti totta, että blues - - on välitöntä seurausta ristiriidoista, jotka ovat ominaisia yhteiskunnalle, jossa aineelliset ja henkiset arvot eivät palvele ihmistä. - - Ainoa mahdollisuus on selittää blues esteettisesti "huonoksi" taiteeksi, ja tässä tämän selityksen harrastajat tulevat kohtaamaan vaikeuksia. Ei näet voida löytää yleispätevää estetiikan järjestelmää, jonka nojalla voitaisiin todistaa, että Neuvostoarmeijan kuoron esitykset tai jopa Shostakovitshin sinfoniat olivat arvokkaammat kuin blues.

\section{populaarikulttuuri:}

Itse käsitän populaarikulttuurilla sellaista massojen tai eliitin kulttuuria, joka on syntynyt vastakohdaksi tai täydennykseksi yläluokan kulttuurille. Populaarikulttuuri on synnyltään antiporvarillista kulttuuria, käyttivätpä sitä sitten hyväkseen sosialistit tai rahaa tekevät kansansumuttajat. - - Kumpikin, sekä eliittikulttuuri että populaarikulttuuri ovat kehittäneet itselleen omat esteettiset lakinsa, omat järjestelmänsä ja keinonsa tuomita sopeutumattomat ainekset "mauttomiksi" tai huonoiksi. Kummassakin kulttuurissa on muodostunut oma hierarkiansa eliitteineen, joka omaa tendenssin muuttua "taiteeksi". Oskar Merikannon kesäillan valssia ei yleensä pidetä taiteena, vaikka se selvästi kuuluukin yläluokan taiteeseen, Joonas Kokkosen III sinfoniaa sen sijaan pidetään taiteena. - - The Mothers of Invention -yhtye uskoo melko varmasti luovansa taidetta ja lisäksi uuttaluovaa taidetta, sen sijaan tyypillisintä Hollywoodin filmimusiikkia eivät edes sen säveltäjät pitäne taiteena.

sosialistinen kulttuuri:

Eleazar Baller kertoo, että eräs Leninin ensimmäisistä "kulttuuri"teoista oli kaataa Leningradin ja Moskovan keisarien ja heidän suosikkiensa kunniaksi pystytetyt muistopatsaat ja korvata ne Marxin, Radistshevin, Shevtshenkon, Kaljajevin, Halturinin, Robespierren, Tshernyshevskin ja Plehanovin patsailla. Mikä sosialistisen uudelleenluonnin ironia! Baller saattaa olla siksi tyhmä, että esittää tämän seikan aivan tosissaan esimerkiksi Leninin sosialistisesta kulttuuritahdosta; Lenin itse luultavasti oli samaa mieltä kuin Marx luettuaan Paul Lafarguen kirjoittaman selostuksen marksilaisuudesta: Jos tämä on marksilaisuutta niin minä en ole marksilainen!

\section{kulttuurikolonialismi:}

Kulttuurikolonialisteja ovat ne, jotka uskovat Kalevalaa paremmaksi kuin Ramayanaa, ne jotka uskovat konserttimusiikkia paremmaksi kuin bluesia, ne jotka pitävät Väinö Linnaa taiteena mutta eivät Hiski Salomaata. - - Tangoa vastustaessaan ja bluesia vastaan hyökätessään - - suomalainen sosialisti itse asiassa tukee Euroopan kulttuuri-imperialismia, joka ikuisia, faustisia arvoja etsiessään on jo tuhonnut melkein kokonaan usean ulkoeurooppalaisen kulttuurin.

\section{kulttuuripolitiikka:}

[O]n yhtä perverssiä tarjota ihmisille vain Nyyrikkiä kuin tarjota vain Parnassoa. Kulttuuria voidaan ohjata, mutta sitä ei voida ohjata kieltämällä ihmisiltä totaalisesti se mitä he - syystä tai toisesta haluavat, ei liioin vaatimalla suurempia rahallisia suorituksia eitoivottavan taiteen hankkimisesta. Tämä on ollut sekä suomalaisen alkoholipolitiikan että kulttuuripolitiikan suunta - kummatkin ovat kauniissa tavoitteissaan surkeasti epäonnistuneet.

Kärkevässä jutussa Saunio tuli sohaisseeksi myös musiikin ulkopuolisia arvokysymyksiä, mikä aiheutti moniviikkoisen polemiikin Kansan Uutisissa. Toimittaja Max Rand oli erityisen tuohtunut siitä, että "sosialistina esiintyvä liberaali" Saunio saattoi puolustaa roskakirjallisuutta ja Hannu Vuorio selitti Saunion populaarikult- 
tuurikäsityksen vääräksi marxilaisen teorian valossa. Saunion rinnalle asettui puolestaan Pekka Gronow, joka näyttää olleen Ilpon läheisin hengenheimolainen kulttuuripoliittisissa kysymyksissä.

En kuitenkaan usko, että Ilpon kulttuurikriittisyys oli pelkästään henkilökohtainen ominaisuus. On luultavaa, että musiikin alueella kulttuuriset ristiriidat tulivat yksinkertaisesti selvemmin esiin kuin esimerkiksi kirjallisuudessa. Taidemusiikin julkisuudessa autonomiaestetiikalla oli jo lähes satavuotiset perinteet myös Suomessa. Sen sijaan kirjallisuudessa autonomiaestetiikka syntyi oikeastaan vasta 1950-luvun modernismin yhteydessä; vasta tuolloin Suomeen muodostui "kirjallinen osakulttuuri", jolla oli sisäiset arviointiperusteet hyvän ja huonon kirjallisuuden suhteen (vrt. Alapuro 1997, 118). Nuoren kirjallisuuseliitin oli helpompi puolustaa vakiintunutta estetiikka kuin Ilpon kaltaisten muusikoiden, joiden silmissä autonomiaestetiikka näytti täysin aikansa eläneeltä.

Joku tarpeeksi epäpoliittinen tai poliittisesti viaton lukija saattaa edelleen ihmetellä, mitä musiikin arvokeskustelulla ja musiikkipolitiikalla on suomalaisen etnomusikologian kehityksen kanssa. Selitän asian vielä kertaalleen, ihan vain varmuuden vuoksi. On varsin kiistämätöntä, että amerikkalaistyyppinen etnomusikologia kiinnittyi akateemisen musiikkitieteen kylkeen yhtenä reaktiona 1970-luvun vaihteen musiikin arvokeskusteluun.

Kaikki 1970-luvun etnomusikologit eivät varmastikaan olleet vasemmistolaisia, eivätkä kaikki olleet kiinnostuneet populaarimusiikistakaan. Oli myös niitä, joille etnomusikologia merkitsi pelkästään kansanmusiikin, itäisten korkeakulttuurien tai alkuperäiskulttuurien musiikkien akateemista tutkimista. Mutta meitä kaikkia yhdisti ajatus musiikillisten arvojen suhteellisuudesta ja kulttuurisidonnaisuudesta. Tällainen ajattelu oli lähes kaikille tuon ajan musiikkitieteilijöille täysin vieras, ja tässä mielessä Ilpo Saunion kaltaisten vasemmistoradikaalien julkinen kulttuuripolemiikki kuuluu ilman muuta suomalaisen etnomusikologian peruspilareihin. Osa Ilpon argumenteista saattaa kuulostaa nykyisin kovin ehdottomilta. Tämä johtunee kuitenkin siitä, että suomalainen kulttuuri-ilmasto on muuttunut kovin paljon 30 vuoden aikana. Ainakin minun mielestäni muutos on tapahtunut juuri siihen suuntaan, johon Ilpo Saunio kirjoituksillaan pyrki.

\section{Instituutti-Ilpo}

Aiemmasta kriitikontoimesta jäi jäljelle oikeastaan vain yksi alue, jolla Ilpo Saunio kunnostautui pitkälle 1980-luvulle saakka: kuorokonserttien ja levytysten arviointi ja esittely. Tässä tapauksessa työ ei välttämättä vastannut Ilpon musiikillisia mieltymyksiä - itse en kuullut Ilpon koskaan ilmaisevan suurempaa kiinnostusta kuoro- 
laulua kohtaan. Kuorokonserttien arviointi oli Ilpolle selkeää kulttuuripolitiikkaa. Ensinnäkin juttujen kohteena olivat vain ja ainoastaan työväen musiikkiryhmät ja liikettä lähellä olevat taiteilijat, joiden toiminta Kansan Uutisten kulttuuritoimituksen oli luonnollisesti välttämätöntä seurata. Toiseksi kyseessä olivat yleensä helsinkiläiset amatöörikuorot - mm. Koiton laulu ja Kulttuuritalon kuoro, joilla oli näkyvä sija työväenliikkeen kulttuurihistoriassa ja järjestötoiminnassa. Ilpon oli helppo tulkita tällainen kuorolaulu edistykselliseksi populaarikulttuuriksi. Kolmas syy oli mahdollisesti hyvin yksinkertainen. Kansan Uutisilla ei ollut välttämättä ketään muutakaan avustajaa, joka olisi ollut valmis harrastusmusiikin kriitikoksi, ja Ilpo teki työtä käskettyä.

Lähempi suhde Ilpolla näyttää olleen uuden laululiikkeen musiikkiin. Näin oli ehkä siksi, että hän koulutettuna muusikkona arvosti musiikin ammattitaitoa. Ilpon leikekirja onkin pullollaan konserttikatsauksia, joissa esitellään laululiikkeen tunnetuimpia taiteilijoita. Nimet Chydenius, Donner, Edelman, Valpola, Ojanen, Agit Prop, Liisa Tavi ja monet muut tulevat vastaan tuhka tiheään. Ilposta tulikin poliittisen laululiikkeen hoviarvostelija, ja liikkeen musiikintekijät myös ilmeisesti pitivät Ilpon asiantuntevuutta korkeassa arvossa.

Vanhemmasta työväenlaulusta, aatteellissävyisestä kansanlaulusta tuli kuitenkin se alue, joka vei Ilpo Saunion mukanaan. Tästä aiheesta syntyivät kaikkein laajimmat ja perusteellisimmat tutkielmat, mm. kaksi paksua kirjaa (Saunio 1974; Saunio \& Tuovinen 1978). Lisäksi työväenlaulututkimus ja siihen olennaisesti liittynyt laaja keruuprojekti olivat lähtökohtana siihen, että Ilpo Sauniolle saatiin perustettua mittojen mukainen työpaikka, Työväenmusiikki-instituutti.

Instituutin perustamiseen liittyvät tapahtumat kuvaavat hyvin sitä suomalaisen kulttuurin säätelyn järjestelmää, joka erityisesti 1970-luvulla kehittyi valtionapuvetoiseksi ja puoluepoliittiseksi. Pitkälti Kaustisen kansanmusiikkijuhlien ja siihen liittyneen kansanmusiikki-innostuksen vanavedessä Kaustiselle oli saatu perustetuksi jo vuonna 1974 Kansanmusiikki-instituutti, jonka tehtäväksi tuli kansanmusiikin harrastustoiminnan ohjaus ja sitä palveleva tutkimus. Noihin aikoihin opetusministerinä oli Keskustapuolueen Marjatta Väänänen, eikä poliittisen keskustan tukea Kaustisen instituutin synnyttämisessä kannattane vähätellä. ${ }^{4}$ Maaseutu-Suomen

\footnotetext{
${ }^{4}$ Samoihin aikoihin osuu myös Tampereen yliopiston nykyisen etnomusikologia-oppiaineen perustaminen, jossa ministeri Väänäsellä ja hänen neuvonantajillaan lienee myös ollut ratkaiseva rooli. Se että oppituolin nimeksi tuli hyvin erikoinen "kansanperinne, erityisesti kansanmusiikki", jolla ei ole mitään kiinnityskohtaa tai esikuvaa minkään muun maan yliopistoissa, kuvaa mielestäni oppiaineen perustamiseen liittynyttä voimakasta tiede- ja kulttuuripoliittista painotusta. Kiintoisana yksityiskohtana mainittakoon edesmenneen professori Erkki Ala-Könnin tämän kirjoittajalle kertoma muistikuva, jonka mukaan hän olisi kannattanut oppiaineen nimeksi populaarimusiikin tutkimusta. Se olisi epäilemättä sopinut paremmin ajankohdan kulttuurikeskusteluun ja erityisesti Tampereen yliopiston yhteiskuntatieteelliseen luonteeseen. Ministeriön valitsema kansanperinnelinja veti kuitenkin pitemmän korren.
} 
kansankulttuurin edistäminen on kuulunut Keskustapuolueen lempiaiheisiin, ja se on näkynyt monella muullakin tavalla kuin puolueen johtohahmojen tanhuharrastuksena.

Kaustisen instituutti sai Opetusministeriön budjettiin oman rahoituspaikkansa, ja sen kehitys näytti turvatulta. Valtionapu tosin oli - ja on edelleenkin - harkinnanvaraista, joka vuosi uudelleen anottavaa. 1970-luvun lopulle tultaessa syntyi kuitenkin muita hankkeita, jotka pyrkivät samalle rahoitusväylälle Kansanmusiikki-instituutin kanssa. Vuonna 1978 ruotsinkielinen kansanmusiikkitoiminta sai oman instituuttinsa - epäilemättä Ruotsalaisen kansanpuolueen vahvasti tukemana, ja saman aikaisesti molemmat työväenpuolueet alkoivat ajaa työväenmusiikin tutkimus- ja dokumentointilaitoksen perustamista.

Nämä hankkeet eivät välttämättä olleet Kansanmusiikki-instituutin mieleen, sillä yleensä valtionavut pienenevät, kun rahan jakajia ilmaantuu lisää. Lisäksi Kaustisella oli voimakas intressi laaja-alaisempaan kansanomaisen musiikin tutkimukseen, johon työväenlaulun tallennus- ja tutkimus olisi sopinut hyvin. Kansanmusiikki-instituutin silloinen johtaja Heikki Laitinen kertoo muistavansa elävästi erään suunnittelukokouksen, jossa hän pyrki vielä toimimaan erillisten instituuttien perustamista vastaan (suullinen tieto, 20.3. 2000).

Laitisen mukaan Kaustinen olisi ollut valmis perustamaan Helsinkiin jopa oman filiaalin, jotta työväenlaulukeräyksen tulokset olisi saatu paremmin harrastajien ja tutkijoiden käyttöön. Kokouksessa sosialidemokraattista Työväen sivistysliittoa edustanut Pekka Gronow piti kuitenkin kiinni omasta linjastaan: Ilpo Sauniolle oli saatava vihdoinkin oma työpaikka ja oma instituutti, joka sitten näkikin päivänvalon syksyllä 1979.

Työväenlaulujen keruun ja tutkimuksen taustalla on nähtävissä 1970-luvulle tyypillinen kehitys, jossa vasemmistolainen älymystö synnytti perinteisen topeliaanisen kansakuvan rinnalle uuden version, työväenliikkeen kansakuvan. Työväenliike nähtiin siinä suuren kansallisen linjan jatkeena, ja työväen kulttuurille haluttiin saada samanlainen arvostus ja asema kuin kansallisen liikkeen esiin nostamalle talonpoikaiskulttuurille. Risto Alapuron (mts., 144-145) mukaan ilmiön taustalla oli se, että uusi vasemmistoälymystö kaipasi 'kansan' solidaarisuutta samalla tavalla kuin vuosisadan alun fennomaanit olivat kaivanneet talonpoikien tukea.

Alapuron tulkinta saattaa olla hyvinkin osuva, erityisesti jos sitä soveltaa taistolaisliikkeen kulttuurityöhön. Mutta ainakin Ilpo Saunion kohdalla työväenlaulujen esiintuontiin liittyi toinenkin piirre, nimittäin kansainvälisyys. Niinpä Ilpon ensimmäinen työväenmusiikkia koskeva kirja Veli sisko kuulet kummat soitot (1974) oli nimenomaan kansainvälisen työväenliikkeen poliittisen laulun historia. Vasta seuraava teos Edestä aattehen (1978) keskittyi suomalaisiin työväenlauluihin.

Myös myöhemmissä kirjoituksissaan Ilpo Saunio pyrki liittämään työväenlaulut laajempaan populaarikulttuurin syntyhistoriaan. Hänelle populaarikulttuuri oli jota- 
kin muuta kuin massojen kaupallista tai ideologista manipulaatiota, jota länsimaiset kulttuurikriitikot Adornon jalanjäljissä toistelivat. Kuten edellä kävi ilmi, sama ajatus oli keskeinen myös reaalisosialismin virallisissa kulttuurinäkemyksissä. Ilpolle populaarikulttuurin ydin oli aidosti porvarillisen taiteen vastakohta, ja sen loistavimmat esimerkit löytyivät eri maiden köyhälistön lauluista.

Populaarimusiikin tutkimuksen edistämisestä ja sen arvostuksen lisäämisestä tulikin Ilpo Saunion ja hänen instituuttinsa varsinainen tehtäväalue. Työväenlaulullakin oli ollut oma, suhteellisen lyhyt renessanssinsa 1970-luvun puolivälissä. Mutta kun Työväenmusiikki-instituutti oli kokenut päivänvalon, uuden laulun liikkeeltä oli jo todellinen potku kadonnut. Tässä mielessä Ilpon instituutin perustaminen oli epäilemättä myöhäsyntyistä, jos tällainen jälkiviisastelu sallitaan. Siitä ei voinut tulla kansanmusiikki-instituuttien kaltaista harrastajien palvelulaitosta, sillä harrastajat alkoivat olla jo 1980-luvulla vähissä.

Sen sijaan ei ole syytä aliarvioida sitä merkitystä, mikä Työväenmusiikki-instituutilla oli 1980-luvun suomalaiselle etnomusikologialle. Instituutista eli Tuutista tuli erityisesti helsinkiläisten etnomusikologien tukikohta, joskin sen ilmapiiri oli aluksi lähes shokeeraava yliopiston laitosten hiljaisuuteen tottuneille. Ainakin itselleni Ilpon instituutti merkitsi varsinaista nuoruuden yliopistoa. Se oli paikka, jossa johtaja näytti muille mallia niin työnteon kuin vapaa-ajanvieton ankaruudessa. Samalla nuorempi polvi sai olla aitiopaikalla kuulemassa loppumattomia mahtijuttuja 60-luvun radikaali-sankareista.

Hyvin pian myös Suomen etnomusikologisen seuran toiminta siirtyi Tuutin suojiin. Kokeneena toimittajana Ilpolta ei mennyt kauan, kun hän jo suunnitteli seuran julkaisujen tuotantoa - ensin jonkinlaisena takapiruna ja sittemmin Musiikin Suunnan päätoimittajana. Seuraava kommentti kertoo siitä, minkälaisella gonzomielellä seuraa vedettiin tuohon aikaan. Ilpolle akateeminen jäykkyys oli erittäin mieluisa pilkan kohde. Kommentin hauskuus saattaa jäädä tavoittamatta, ellei ole perillä ajankohdan tapahtumista pienen tiedeyhteisömme ympyröissä. Mutta toisaalta hyvät vitsit kuluvat, jos niitä selittää liiaksi. Tuon ajan läheltä nähnyttä Ilpon esimerkit jaksavat vieläkin hymyilyttää:

Tiedotuslehti omalle jäsenistölle on kolmas eikä välttämättä vähäpätöisin taso. - Tiedotuslehden ominta aluetta ovat tietysti tiedeuutiset (Erkki Pekkilä löytänyt uuden musiikin muodon Japanista), tapahtumakalenteri (Slobo Horo 31.12. klo 24.00 Senaatintorilla, juhlapuhe ylipormestari Raimo Ilaskivi), uutuuslistat (Philip Donnerin väitöskirjasta 7. painos, 834 s., Oxford University Press) ja keskustelupalsta (Oramon projekti kähminyt jälleen kaikki apurahat). (Saunio 1988)

Ilpon instituutin olemus oli varsinkin aluksi sangen poliittinen. Se mm. merkitsi, että kaikki siellä tehtävä työ sai voimakkaan vasemmistolaisen sävyn. Virisipä instituutin piirissä niinkin suurisuuntaisia ja kieltämättä utopistisia suunnitelmia, että laitoksesta olisi tullut yleisempi suomalaisen musiikkikulttuurin tutkimuskeskus, 
joka olisi tarkastellut asioita työväenliikkeen näkökulmasta.

Esikuva löydettiin ei vähempää kuin Työväen Taloudellisesta tutkimuslaitoksesta, sehän piti noina vuosina varsin korkeaa profiilia talouspoliittisessa keskustelussa. Idea oli sinällään hyvä, mutta ei toteuttamiskelpoinen. Ilpo Saunio sai 1980luvun mittaan hyvinkin karvaasti kokea sen mitä työväenliikkeen paljon puhuttu kulttuurihenkisyys käytännössä tarkoitti tai oikeastaan mitä se ei tarkoittanut. Se ei tarkoittanut ainakaan sitä, että Työväenmusiikki-instituutti olisi saanut taloudellista tukea liikkeen sisältä.

Poliittisuudesta oli siten enemmän haittaa kuin hyötyä. Silti yhteiskunnallinen pohdiskelu vastasi hyvin Ilpo Saunion ajattelutapaa. Hänelle etnomusikologia oli hyvä keino niin marxilaisen musiikintutkimuksen kehittelyyn kuin vasemmistolaisen kulttuuripolitiikan uudistamiseen. Tämä käy hyvin ilmi kommentissa, jonka Ilpo laati vuonna 1983 sangen pessimistisessä arviossaan, joka käsitteli Suomen Kommunistisen Puolueen kulttuuripolitiikkaa:

\begin{abstract}
Minua on vaivannut aina se, että vasemmistolainen kulttuuripolitiikka pyritään yleensä - ja vasitenkin silloin kun ohjelmia laaditaan - ankkuroimaan filosofiasta johdettuihin esteettisiin rakennelmiin, joilla on hyvin vähän jos ollenkaan kosketuskohtia yhteiskunnan todellisiin kulttuuritrendeihin. Kaikkein vähiten tällaisilla rakennelmilla on tietysti ollut kosketuskohtia duunarin ajatusmaailmaan. Pahinta kaikessa on turvautuminen "kulttuuri kuuluu kansalle" ja muihin vastaaviin iskulauseisiin, joissa jää määrittelemättä mitä on kulttuuri ja mitä on kansa. Riittävässä määrin ristiriitaisuuksia sisältyy myös niihin teoreettisiin lähtökohtiin, joiden avulla on pyritty selvittämään massakulttuuria ja kulttuuriteollisuutta (Adorno ym.) Huomattavasti paremmin on yhteiskunnallista todenmukaisuutta kyetty lähestymään eräissä kulttuurisosiologisissa, kulttuuriantropologisissa ja etnomusikologisissa tutkimuksissa, jotka itse asiassa monilta aspekteiltaan edustavatkin sitä mitä marxilaisen kulttuurintutkimuksen pitäisi periaatteessa olla: todellisuuslähtöistä empiiristä tiedettä, joka tutkii oman aikansa yhteiskuntaa kuten Marx ja Lenin aikanaan. (Saunio 1983, 58).
\end{abstract}

Tuossa vaiheessa Ilpo Saunio oli jo käytännössä entinen kommunisti, joka oli kyllästynyt vuosikausia kestäneisiin osapuolikiistoihin taistolaisten ja enemmistöläisten välillä. Tästä huolimatta Ilpo jaksoi toimia aktiivisesti mm. Helsingin laulufestivaaliyhdistyksessä ja Suomi-Neuvostoliitto-seuran musiikkijaostossa. Niistä varsinkin edellinen kantoi mukanaan 1970-luvun taistolaisliikkeessä syntyneitä luokkakantaisia päämääriä, vaikka festivaalin ohjelma pyrittiinkin laatimaan epäpoliittiseksi ulkoeurooppalaisen ja muun vaihtoehtoisen musiikin esittelyareenaksi. Jostain syystä esiintyvät taiteilijat vaan sattuivat säännöllisesti tulemaan Euroopan ja kolmannen maailman sosialistisista maista tai olivat muuten kansainvälisesti tunnettuja kommunisteja.

Huonosti peitelty äärivasemmistolaisuus ei ollut enää 1980-luvulla hyväksi, jos mieli yhteiskunnallista tukea tai kaupallisia sponsoreita. Helsingin laulufestivaalilla oli niin huono imago, ettei siitä voinut tulla maailmanmusiikin lipunkantajaa Suomessa. Niin ei käynyt vaikka Ilpon kaltainen asiantuntija oli festivaalin johdos- 
sa ja vaikka maailmanmusiikista oli tullut median lempilapsi 1980-luvun lopulla. Tarvittiin Työväenmusiikki-instituutin nimen muuttamista Maailman musiikin keskukseksi, uusia ihmisiä ja organisaatioita, ennen kuin niinkin luonteva yhteistyötaho kuin Helsingin kaupunki päätti ryhtyä tukemaan tuntuvammin Ilpo Saunion festivaali-idean jatkajia. Vuonna 2000 entinen Työväenmusiikki-instituutti huolehtii Helsingin kulttuurivuoden etnisen musiikin klubituotannosta. Mutta nyt eletäänkin euro-aikaa.

1970-luvulta oli peräisin myös Ilpon innostus Saksan demokraattiseen tasavaltaan ja erityisesti sen poliittisen laulun liikkeeseen. Ilpohan oli vanha Saksan ystävä, jo 1950-luvun lopulla Kölnissä opiskellut. Ystävyys näkyi mm. silmittömänä makkaransyönti- ja oluenjuontiharrastuksena. Työväenmusiikki-instituutin johtaja oli jokavuotinen vieras Berliinin poliittisen laulun festivaalilla, ja suomalaiset työväenlehdet saivat perusteellisia reportaaseja noista DDR-sosialismin riemujuhlista.

On jälkeenpäin huikeaa ajatella, että Ilpon innostusta riitti aina 1980-luvun jälkipuolelle saakka. Jokainen DDR:ssä vieraillut saattoi kokea tuon turvavaltion ahdistavan kontrollihengen, eikä Ilpon kaltainen ikuinen kapinallinen voinut olla aistimatta samaa. Mutta kuten useimmat sosialististen maiden kanssa tekemisissä olevat suomalaiset tuohon aikaan, Ilpo ei nostanut kriittisiä ajatuksiaan julkisuuteen. Yksityiset kommentit olivat usein sitäkin rankempia.

Olen silti löytänyt yhden kriittisyyteen viittaavan kirjoituksen. Se on vuodelta 1984, jolloin Ilpo osallistui suomalaisten esiintyjien mukana Leipzigin Hanns Eisler -kuorofestivaaliin ja sen yhteydessä pidettyyn seminaariin. Kritiikki on peiteltyä, mutta Ilpon tyylin tunteva voi aistia voimakkaamman jurppimisen rivien välistä:

\footnotetext{
Kahtena aamupäivänä kokoontui lähes satapäinen ja paitsi kansainvälinen, hyvinkin arvovaltainen symposium aiheenaan "Laulu aikamme poliittisissa taisteluissa. Traditioita, metodeja, vaikutuskenttiä". Valitettavasti arvovaltaisuus ei aina merkinnyt samaa kuin kiinnostavuus. Symposiumin pääalustaja prof. Jürgen Elsner Berliinin Humboldt-yliopistosta pyöritteli tunnin ajan erilaisia tavanomaisuuksia ja itsestäänselvyyksiä hyväntahtoisella ongelmattomuudellaan, ja muiden sosialististen maiden edustajat tyytyivät melko alkeellisiin sävellys- ja säveltäjäluetteloihin omasta maastaan. Vauhtia keskustelu sai vasta toisena aamuna, jolloin Suomen puheenvuoron pitänyt Kaj Chydenius räjäytti pankin kysymällä avoimesti, missä ovat DDR:n säveltäjät, mitä he tekevät ja onko tässä maassa ylipäätään ongelmia. Toisen kapitalistisen maan, Itävallan edustaja Wilhelm Zobi - - jatkoi taistelevan laulun ongelmien kritiikkiä mm. kertomalla Wienissä pidetystä mielenosoituksesta, jossa ei haluttu demonstroida mitään. Keskusteluhalukkuutta syntyi, mutta aika alkoi olla vähissä. Niinpä yksi jos toinen osanottaja poistui symposiumista saalis vähäisenä ja mieli kapinallisena. (Saunio 1984, 13).
}

Kaikesta huolimatta Ilpo pysyi suurena DDR:n ystävänä sairastumiseensa asti joulukuussa 1988. Olisi suurta jälkiviisastelua ihmetellä miksei olisi pysynyt. Vain harvat osasivat aavistaa sirppi ja vasara -systeemin nopean lopun; ei edes Suomen ulkopoliittinen johto siihen kyennyt.

Ennen sairastumistaan Ilpo ehti silti luoda instituutilleen myös uusia suuntia, nyt 
yhä enemmän kolmannen maailman musiikkikulttuureihin. Hänen suunnitelmissaan oli isoja koulutus-, dokumentointi- ja äänilevyprojekteja mm. Etiopiaan, Tansaniaan ja Kuubaan. Monet niistä ovat sittemmin toteutuneet, tavalla tai toisella. Mutta kukaan meistä ei tiedä, mitä niistä olisikaan tullut Ilpon johdolla.

\section{Lähteet}

Alapuro, Risto 1997. Suomen älymystö Venäjän varjossa. Helsinki: Tammi.

Anonyymi 1962. Sinfoniakonserttien ohjelmat kuulijoiden kritiikin kohteena. Uusi Suomi 25.2.1962.

Gronow, Pekka 1969. Populaarikulttuurin teoria ja käytäntö. Kansan Uutiset 5.8.1969.

Gronow, Pekka \& Ilpo Saunio 1970. Äänilevytieto. Levyhyllyn käsikirja. Porvoo - Helsinki: WSOY.

Gronow, Pekka \& Ilpo Saunio 1990. Äänilevyn historia. Porvoo - Helsinki - Juva: WSOY.

Gronow, Pekka \& Ilpo Saunio 1999. An International History of the Recording Industry, transl. Christopher Moseley. London - New York: Cassell.

Rand, Max 1969. James Bond ja Carter Brown sosialismin rakentajina. Kansan Uutiset 27.7.1969.

Saunio, Ilpo, toim. 1966. Afrikka-numero. Terä 13/1966.

Saunio, Ilpo 1967. Akateemikko Kokkonen erehtyy. Kansan Uutiset 9.7.1967.

Saunio, Ilpo 1969. Populaarikulttuuri, kulttuuriperinne ja marxilaisuus. Kansan Uutiset 23.7.1969.

Saunio, Ilpo 1971. Musiikki on cannabista kansalle. Kansan Uutiset 24.1.1971.

Saunio, Ilpo 1974. Veli sisko kuulet kummat soitot. Työväenlaulut eilen ja tänään. Helsinki: Kansankulttuuri.

Saunio, Ilpo 1983. Haarukassa kulttuuri. Kulttuurivihkot 3/1983.

Saunio, Ilpo 1984. Leipzigin Hanns Eisler -festivaali loisteliaasti organisoitu, ajatuksia herättävä. Työväen Sävel 3/1984.

Saunio, Ilpo, toim. 1986. Etiopian musiikki. Musiikin suunta 4/1986.

Saunio, Ilpo 1988. Lukijalle. Sessio 2/1988.

Saunio, Ilpo ja Timo Tuovinen 1978. Edestä aattehen. Suomalaisia työväenlauluja 1890-1938. Helsinki: Tammi.

Saunio, Ilpo ja Kalevi Immonen 1979. Pororumpu ja balalaikka. Neuvostoliiton kansojen musiikki. Helsinki: Työväenmusiikki-instituutti.

Toiviainen, Seppo 1970. Yhteiskunnalliset ja kulttuuriset ristiriidat - musikologisten osakulttuurien sosiologista tarkastelua. AUT ser. A vol. 39. Tampere: Tampereen yliopisto.

Vuorio, Hannu 1969. POP-, eliitti- ja luokkakulttuurista. Kansan Uutiset 10.8.1969. 